\title{
Lead and haemoglobin synthesis: a review
}

\author{
J. M. WHITE \\ M.D. \\ Department of Haematology, Royal Postgraduate Medical School, Du Cane Road, London
}

IT has been known for many years that lead poisoning is associated with both abnormal haemoglobinization of the red cell and red cell production. Thus Gould, Kullman and Shecket noted in 1937 that the treatment of cancer patients with lead resulted over several weeks in a progressive anaemia, reticulocytosis and erythroblastosis. Basophilic stippling of red cells was a prominent feature. Recently it has been realized that lead exposure does not invariably lead to anaemia in the adult, although in children it may be marked (Albahary, Guillaume and Martin, 1965; Boyett and Butterworth, 1962; Hutchinson and Stark, 1961; Watson, Deckers and Lichtman, 1962). The bone marrow morphology shows normoblastic hyperplasia and the presence of abnormal ringed sideroblasts, the last of which indicates that the controlled synthesis of haemoglobin within the cell is abnormal. This has now been confirmed by the finding that the synthesis of both globin and haem were inhibited by inorganic lead in vitro.

Much of the early work concerned the effect of lead on haem synthesis. As early as 1895, Stokvis showed that in lead-poisoned rabbits there was an increased excretion of porphyrins. Later, increased excretion of coproporphyrin and $\delta$-aminolaevulinic acid were found in man (Grotepass, 1932; Haeger, 1957). Bessis and Breton Gorius (1959) pointed out that lead produced morphological changes of the mitochondrion in that the cristae were swollen and disorganised. It is now known that lead in vitro inhibits ALA dehydratase, ferrochelatase and coproporphyrinogen oxidase (Dresel and Faulk, 1956; Goldberg et al., 1956). The mechanism of inhibition is thought to be due to blockade of $-\mathrm{SH}$ groups which these enzymes possess. However, there is no evidence that the $-\mathrm{SH}$ groups are near the active site of the enzyme, nor that $-\mathrm{SH}$ blockade would result in their inactivation.

Present data, however, indicate that these enzymes are inactivated and this results in a deficiency of haem within the cell and an increased accumulation and excretion of haem intermediates. There are also data which indicate that total globin synthesis is inhibited but it is not known whether this is a primary abnormality or a secondary effect caused by heam deficiency. (Kassenaar, Morell and London,
1957). To answer these questions a systematic study has been carried out on the effect of lead on globin, and $\alpha$ and $\beta$ chain synthesis in vitro with and without the addition of haemin. The methodology and results have been reported in detail elsewhere (Piddington and White, 1974) and only an outline of the experiments and implication of the findings will be given here.

In vitro, using reticulocytes from patients with haemolytic anaemia, it was found that total globin synthesis was markedly inhibited by lead and the degree of inhibition was dependent on the concentration over a range of 25-500 $\mu \mathrm{g}$ (Table 1). Similarly, there was a depression of $\alpha$ and $\beta$ chain synthesis $(\alpha: \beta<1.0)$ (Table 2). Also $\alpha$, chain synthesis was significantly more depressed than $\beta$ chain synthesiso at least until the concentration of lead reached $200 \mu \mathrm{g} / 100 \mathrm{ml}$. The addition of haemin to the system at concentrations of $10^{-3} \mathrm{~mol} / 1$ corrected tota globin chain synthesis but only partially corrected

TABLE 1. The effect of lead on total globin synthesis with and without added haemin

\begin{tabular}{ccc}
\hline $\begin{array}{c}\text { Lead conc. } \\
(\mu \mathrm{g} / \mathrm{dl})\end{array}$ & $\begin{array}{c}\text {-haemin } \\
(\% \text { inhibition })\end{array}$ & $\begin{array}{c}+ \text { haemin } \\
(\% \text { inhibition })\end{array}$ \\
\hline 50 & 20 & 3 \\
100 & 40 & 5 \\
200 & 57 & 9 \\
400 & 74 & 7 \\
\hline
\end{tabular}

The results given are the mean values of seven experiments. The lack of inhibition in the presence of haemin is highly significant.

TABLE 2. The effect of lead on the relative synthesis of $\alpha$ and $\beta$ chains with and without added haemin

\begin{tabular}{ccc}
\hline $\begin{array}{c}\text { Lead conc. } \\
(\mu \mathrm{g} / \mathrm{dl})\end{array}$ & $\begin{array}{c}\text { - haemin } \\
\alpha: \beta\end{array}$ & $\begin{array}{c}\text { +haemin } \\
\alpha: \beta\end{array}$ \\
\hline 0 & 1.06 & 1.07 \\
50 & 0.99 & 1.05 \\
100 & 0.91 & 1.03 \\
200 & 0.86 & 1.00 \\
400 & 0.80 & 0.92 \\
\hline
\end{tabular}

The results given are the mean values of of five experiments. The difference in the ratios, with and without haemin, is proably insignificant. 
the imbalance between $\alpha$ and $\beta$ chains (Tables I and II). Studies also showed that the transport of the isotope label used ( ${ }^{3} \mathrm{H}$ leucine) into the reticulocyte, was markedly inhibited. Although this finding may partially explain the inhibition of total globin synthesis, it would not account for the relatively greater inhibition of $\alpha$ chains, in that both chains have the same number of leucine residues. Using an isotope of lead $\left({ }^{203} \mathrm{~Pb}\right)$, a significant, yet small amount was found associated with the ribosomal fraction of the cell. These in vitro findings indicate that the inhibitory effect of lead on globin synthesis acts at two levels-the first, and major effect, is secondary to haem deficiency, and the second is probably due to the effect of lead per se. With regard to the first effect, the pattern of inhibition of globin synthesis is strikingly similar to that found in other haem deficiency states, namely iron deficinecy (White and Hoffbrand, 1974) and sideroblastic anaemia (White, Brain and Ali, 1971). In these disorders, not only was globin synthesis subnormal, but there was a relatively greater inhibition of $\alpha$ chain synthesis than $\beta$ chain synthesis. At present the most likely explanation is that when haem is deficient a soluble inhibitor to globin chain initiation is formed, which is removed by the presence of exogenous haemin (Hunt, Vanderhoff and London, 1972). Since the inhibitory effect of lead can be largely overcome by haem, it is considered that the major effect of lead is an inhibition of haem synthesis which, via the formation of an inhibitor, affects globin synthesis. The evidence that lead has a direct effect upon globin synthesis is at present speculative and based on the fact that haemin did not completely correct the relatively greater inhibition of $\alpha$ chain synthesis, and also that a small, yet significant, amount of lead was bound to the ribosome fraction of the cell. Since in this study only reticulocytes were used, one can only postulate that lead has a direct effect at the level of translation of globin messenger RNA. However, it is also possible that lead may cross, or disturb, the nuclear membrane and affect transcription of the messenger.

These in vitro findings, especially the decrease in the $\alpha: \beta$ ratio, prompted a study into the in vivo synthesis of globin in lead workers as compared with a control group. Twenty-eight lead workers were studied, all of whom had elevated blood lead levels. None, however, had any evidence of lead toxicity. It was found that the $\alpha: \beta$ ratio of this group (mean 1.24) was not statistically different $(P=0.027)$ from the control group (mean 1.041). However, six subjects had ratios greater than $1 \cdot 2$, a finding which was reproducible.

From these findings it is concluded that the supply of haem is not defective in the red cell precursors of these subjects, although from the data of other workers the levels of blood lead are high enough to cause disturbances in the haem pathway. Also, the finding that some workers had an increased rate of $\alpha$ chain synthesis may indicate that during chronic exposure compensation of $\alpha$ chain synthesis takes place and in some instances 'overcompensation' occurs.

There are no data available regarding the changes of the MCH of lead workers at the beginning of their work, but such data should easily be obtained and this is crucial to the hypothesis which has been suggested.

\section{References}

Albahary, C., Guillaume, P. \& Martin, S. (1965) La nocivité hématologique du plomb. Bilan de 40 malades hospitalisés pour saturnisme professionnel. Nouvelle Revue Française d'Hématologie, 5, 689.

Bessis, M. \& Breton Gorius, J. (1959) Étude au microscope électonique du sang et des organes hémopoiétiques dans le saturnisme expérimental. Revue d'Hématologie, 14, 165.

BOYETT, J.D. \& ButTERWORTH, C.E. (1962) Lead poisoning and hemoglobin synthesis. American Journal of Medicine, 32, 884 .

Dresel, E.I.B. \& FaulK, J.E. (1956) Studies on the biosynthesis of blood pigments. II. Haem and porphyrin formation in intact chicken erythrocytes. Biochemical Journal, 63, 72.

Goldberg, A., AshenbruCKer, H., CARTWRight, G.E. \& Wintrobe, M.M. (1956) Studies on the biosynthesis of heme in vitro by avian erythrocytes. Blood, 11, 821 .

Gould, S.E., Kullman, H.J. \& SHECKeT, H.A. (1937) Effectof lead therapy on blood cells of cancer patients. American Journal of Medical Sciences, 194, 304.

GrotePASS, W. (1932) Zur Kenntnis des im Harn auftretenden Porphyrins bei Bleivergiftung. Hoppe-Seylers Zeitschrift für physiologische Chemie, 205, 193.

HAEGER, B. (1957) Increased content of a $\delta$-aminolaevulinic acid-like substance in urine from workers in lead industry. Scandinavian Journal of Clinical and Laboratory Medicine, 9, 211.

Hunt, T., VANDERhofF, G.A. \& London, I.M. (1972) Control of globin synthesis: the role of heme. Journal of Molecular Biology, 66, 471.

Hutchinson, H.E. \& STARK, J.M. (1961) The anaemia of lead poisoning. Journal of Clinical Pathology, 14, 548.

KassenaAR, A., Morell, H. \& London, I.M. (1957) Incor, poration of glycine into globin and the synthesis of heme in vitro in duck erythrocytes. Journal of Biological Chemistry, 229, 423.

Pipdington, S.K. \& White, J.M. (1974) The effect of lead on total globin and $\alpha$ and $\beta$ chain synthesis: in vitro and in vivo. British Journal of Haematology, 27, 415.

Srokvis, B.J. (1895) Zur Pathogenese der Hämatoporphyrinurie. Zeitschrift für klinische Medizin, 28, 1.

Watson, R.J., Decker, E. \& Lichtman, H.C. (1958) Hematologic studies of children with lead poisoning. Pediatrics, 21, 40.

White, J.M., Brain, M.C. \& Ali, M.A.M. (1971) Globin synthesis in sideroblastic anaemia. I. $\alpha$ and $\beta$ peptide chain synthesis. British Journal of Haematology, 20, 263.

White, J.M. \& HoffBrand, A.V. (1974) Haem deficiency , and chain synthesis. Nature. London, 248, 88. 